\title{
A closer look at the bodily-kinesthetic intelligence in Physical Education classes
}

\author{
Um olhar sobre a inteligência corporal cinestésica em aulas de Educação Física
}

\section{Una mirada sobre la inteligencia corporal cinestésica en clases de Educación Física}

\author{
Vilma Lení Nista-Piccolo - Universidade de Sorocaba | Programa de Pós-graduação em Educação | \\ Sorocaba | SP | Brasil. E-mail: vilma@nista.com.br | 지 оrci
}

Abstract: This article poses a reflection on the pedagogical practices developed during Physical Education classes in school. Intending to move beyond a diagnostic analysis of what concerns this area of knowledge in the school routine, this study aims to present this curricular component highlighted as bodily-kinesthetic intelligence. The change to a comprehensive view of the mind has unveiled human cognition and has enabled the identification of different cognitive forces with contrasting styles. Based on a narrative review, specific to this theme, focusing on pedagogical practices experienced in Physical Education classes, the guidelines on this subject, were analyzed. The main purpose of changing this mindset is to improve intelligence manifestations, by stimulating the individual's innate potentials through opportunities. The considerations highlighted in this analysis allow us to reveal significant points for this area. In light of the principles of the Theory of Multiple Intelligences, this study portrays the importance in the choice of content that is representative of the reality of the receivers, developed through various learning pathways during Physical Education classes in school. The establishment of theoretical principles presented by Howard Gardner greatly contributed to the educational field, with emphasis on teaching through various approaches, allowing Physical Education to interpret the students' performance with a focus on their potentials.

Keywords: School physical education. Bodily intelligence. Pedagogical practices.

Resumo: Esse artigo faz uma reflexão sobre as práticas pedagógicas desenvolvidas em aulas de Educação Física escolar. Com a intenção de ultrapassar uma simples análise diagnóstica dessa área de conhecimento no cotidiano escolar, esse estudo objetiva apresentar esse componente curricular como inteligência corporal cinestésica. A mudança da unicidade para uma visão da pluralidade da mente veio desvelar a cognição humana, reconhecendo forças cognitivas diferentes com estilos contrastantes. A partir de uma revisão narrativa, específica nessa temática, com foco nas práticas pedagógicas vivenciadas nas aulas de Educação Física, foram analisadas as diretrizes apontadas pelos estudiosos no assunto. $\mathrm{O}$ objetivo essencial da mudança desse olhar é aperfeiçoar as manifestações de inteligência, estimulando os potenciais inatos dos indivíduos por meio de oportunidades. As considerações destacadas nessa análise permitem-nos revelar pontos significativos para essa área. À luz dos princípios da Teoria das Inteligências Múltiplas, o texto retrata a importância da escolha de conteúdos representativos da realidade a serem desenvolvidos em aulas de Educação Física escolar, por diferentes rotas de acesso à aprendizagem. A implantação dos princípios teóricos apresentados por Howard Gardner, contribuiu com a área educacional, ressaltando o ensino por várias linguagens, permitindo à Educação Física interpretar o desempenho dos estudantes com o olhar voltado aos seus potenciais.

Palavras-chave: Educação física escolar. Inteligência corporal cinestésica. Práticas pedagógicas. 
NISTA-PICCOLO, Vilma Lení. A closer look at the bodily-kinesthetic intelligence in Physical Education classes.

Resumen: Ese artículo hace una reflexión sobre las prácticas pedagógicas desarrolladas en clases de Educación Física escolar. Con el objeto de superar un mero análisis diagnóstico de esa área del conocimiento en el cotidiano escolar, este estudio tiene como objetivo presentar este componente curricular como inteligencia corporal cinestésica. El cambio de la unicidad hacia una visión de la pluralidad de la mente ha permitido desvelar la cognición humana, reconociendo fuerzas cognitivas diferentes con estilos contrastantes. Sobre la base de una revisión narrativa, específica para este tema, centrándose en las prácticas pedagógicas con experiencia en clases de educación física, las directrices señaladas por los estudiosos en la materia fueron analizados. La esencia de ese cambio de mirada está en la posibilidad de perfeccionamiento de las manifestaciones de inteligencia, enfatizando que ello se realiza mediante las oportunidades que se ofrecen a las personas, de estimulación de sus potenciales innatos. Las consideraciones resaltadas en este análisis permitió descubrir puntos importantes para esta área. A la luz de los principios de la Teoría de las Inteligencias Múltiples, el texto retrata la importancia de la elección de contenidos representativos de la realidad que se puedan desarrollar en clases de Educación Física escolar, por diferentes rutas de acceso al aprendizaje. La implantación de los principios teóricos presentados por Howard Gardner, ha contribuido con el área educacional, resaltando la enseñanza por diversos lenguajes, permitiendo a la Educación Física interpretar el desempeño de los estudiantes con la mirada vuelta a sus potenciales.

Palabras clave: Educación física escolar. Inteligencia corporal. Prácticas pedagógicas. 


\section{Introduction}

Interpreted as a privileged space in learning, the school as an institution presents itself as an environment where people work to educate their pupils. There is always a philosophy substantiating every action therein, while there are also objectives that define the pedagogical processes by means of activities envisioned by teachers.

To envision the school environment as a space, where people develop themselves and where their own lives can be transformed, is to define it as a place of critical reflection of reality.

Physical Education classes are part of the school program within a sequence of disciplines that compose the educational curriculum. This means that this area of knowledge composes the development of pupils and, as such, must offer a range of content that contributes to their lives.

The curricular components play a central role in developing pupils because, through these subjects, defined objectives and goals may be reached. Knowledge is built over the learning process and from the content presented through teaching methods and strategies.

Physical Education is still a point of discussion within the school system, very much by the lack of identity of the content and by the paths chosen to deliver this very content. With the intention of reflecting on the pedagogical practices present in these classes, this article aims to surpass the simple diagnostic analysis of this area as a curricular component since the objective is not only to justify its place in the strutural development of students but to present this area of knowledge as possibilities for the manifestation of bodily-kinesthetic intelligence.

With a narrative review of the specific literature on this intelligence, focusing on the experiences in Physical Education classes, this article's objective was to analyze the fundamental issues in the production of scientific theories. Narrative review articles allow teachers access to a broad range of scientific research. In a narrative review article, the author does not explicitly specify the bibliographic search method. It is a critical analysis of scientific production, enabling knowledge building without reproducing quantitative data.

\section{Physical education at school}

The importance of Physical Education in the school context has reached new proportions with the release of official documents under government guidance. These include guiding 
principles for the practice, reflect on the content through transversal issues and introduce the creation of projects. From a different analytical perspective, however, it is possible to observe that the plurality present in the concepts in which these documents are based have generated misinterpretations in the application of conceptual, procedural, factual and behavioral contents.

Educators who discuss pedagogy in different studies criticize the centralization of content over the form. For instance, they emphasize that the problems in the school environment are caused by the confusion between the elaboration and the production of knowledge (MOREIRA; NISTA-PICCOLO, 2009, p. 21, our translation).

There are, however, diverging conceptions about content, in not only Physical Education, and these are often revealed through the teachers' debate and in various publications.

The teaching content involves knowledge that contemplates ideas and concepts, norms and rules, habits and attitudes, facts and convictions, apart from the social experiences enabled through actions and mediated by teaching processes, learning theories, and day-to-day practices. These must serve as a pathway with a focus on transforming the reality and not as a single or unique truth.

In Physical Education classes, the different contents are conceived under a range of knowledge and presented through various subjects. These contemplate a range of stimulation and motor improvement models based on facts and concepts of the area. Thus, we highlight the content to be developed in these classes is the teaching of basic elements of bodily culture in its different possibilities of expression.

Correia (2011) emphasizes that the specific Physical Education knowledge, articulated with other curricular components, is part of the learning culture developed at different educational levels.

[...] School Physical Education should contain knowledge that is justified, especially social relevance, insofar as certain contents, whether conceptual, procedural, attitudinal or valuative, will represent cultural selections, and political and pedagogical choices. The dimension of this process of justification, and then, of legitimation, will be implemented in proportion to the emphases and omissions that are rescued and systematized based on themes of body culture and movement (CORREIA, 2011, p. 78, our translation).

What to teach in Physical Education classes is the ever-present question in the school reality, not only by the educators in the field, but also by other people involved in the development of students. However, more important than choosing a thematic modality that is 
culturally determined is the need to offer, through these classes, the opportunities for stimulating individual potentials promoted by activities in which everyone may execute. "It is a space for expression and experience of a movement that is both singular and at the same time collective for the individual” (TOLEDO; VELARDI; NISTA-PICCOLO, 2009, p. 23, our translation).

There are many manifestations of the expression of body culture contemplated in the knowledge realm of Physical Education. Currently, this framework is based on the National Common Curricular Base (BNCC), approved in 2017. Moura (2019) states that several authors pointed out the lack of essential elements of a curriculum in our area of knowledge, leading to the implementation of a standardized program for the subject.

Educators and authors of the field must respect the capacities and abilities of pupils, mediating the construction of knowledge through various pathways that can lead them to understanding. For this, classes must be arranged into a logical organization of subjects, with an evolution of the complexity as the age increases. "Above all, this involves privileging the development of individuals before training them, perceiving their movements as an expression of intelligence, feelings, and intuitions" (NISTA-PICCOLO; MOREIRA, 2012a, p. 15, our translation). This involves articulate knowledge, applied coherently and with the specific characteristics of each age group, legitimizing the presence of Physical Education in the educational development.

The greatest challenge for teachers is recognizing the potential of their pupils and finding a pathway to learning based on their possibilities. In other words, it is necessary to create facilitating tools for the practice of activities under a playful perspective, in the form of exploiting the potentials of movement.

By interpreting Physical Education as a possibility of educational intervention, the teacher may develop ideas with significant experiences in values such as cooperation, participation, and co-responsibility; activities that are based on different approaches or performed through games, gymnastics, dance, combat, circus numbers, and nature activities, along with others contemplated within a historical-cultural context of Physical Education.

The sports phenomenon must be presented in Physical Education classes in school with the characteristics of the environment itself, as a possible practice, not composed as a culturally determined sports modality introduced to the school without observing the specificities of each 
practice. It is important for the student to have contact with and practice sports with various objectives, mainly as a legacy for the search of a healthy lifestyle in the future.

Whatever the style of the teacher, whichever the defined sport modality to teach the contents, these must promote the opportunity of expressing intelligent behavior and stimulate various forms of mastery that may be applied in other contexts.

The content presented, experienced, and discussed in class will never be the same if discussed with different groups of students, or even if they are again introduced to the same group of students under the influence of a variety of environments. Therefore, knowledge is always an unprecedented and original event, different in every situation, as it depends on the surrounding environment and the previous experiences of the teachers and students. The association of knowledge to life is fundamental. That which is experienced is what the individual interacts with, and this can orientate and serve as a platform towards greater understanding. What is experienced is only materialized as learning when this is incorporated into the Self, when this is associated to other daily situations (TOLEDO; VELARDI; NISTA-PICCOLO, 2009, p. 95, our translation).

When teaching refers to specific activities in the curricular component of Physical Education, it is crucial that what be proposed be characterized as discoveries generated by students' experiences, and not as stereotypical models that are imposed as determined practices.

This is a defense of the interpretation of motor practices as the expression of intelligent behaviors expressed in Physical Education classes in school.

\section{Intelligent behaviors}

The human intelligence has been the subject of research for many years by various scholars in different areas of study. Over the last decades, there has been significant progress in cognitive science (studies of the mind) and in neuroscience (studies of the brain), modifying the epistemological concept of intelligence from singularity to plurality. Howard Gardner is one of the current scientists who carried this change in paradigm in his theory, interpreting the intelligence in a multidimensional mindset. For the author " [...] is a pluralist vision of the mind, recognizing many different and separate facets of cognition, recognizing that people have differentiated cognitive forces and contrasting cognitive styles" (GARDNER, 1995, p. 13).

This very scholar is the author of the Theory of Multiple Intelligences, and he highlights that intelligent behavior is always related to the cultural context. He argued for several nonstatistical grounds, showing two of the most important points: the neural and social sides. "On 
the neural side, Gardner mustered evidence from studies of brain-damage patients and the feats of idiot-savants, who, although generally low performers, show prodigious abilities in specialties such as arithmetic computation or piano playing" (PERKINS, 1995, p. 301).

My research group looks at other special populations as well: prodigies, idiot savants, autistic children, children with learning disabilities, all of whom exhibit very jagged cognitive profiles - profiles that are extremely difficult to explain in terms of a unitary view of intelligence. We examine cognition in diverse animal species and dramatically different cultures (GARDNER, 2006b, p. 49).

For Gardner (1994), intelligence is a potential brought by the individual and manifested in various situations, in which there is a need to overcome a problem, whichever it may be. As opposed to what was previously understood, intelligence is not an entity that is fixed in the brain, but a result of a process of the brain. The theory states that there is no priority in the expressions of intelligence for a determined domain; all are processed in the same manner and, therefore, intelligent behaviors cannot be considered different in their relevance.

This theory, by revealing the human cognition, demonstrates that the opportunities of stimulating the inherent potentials are what enable people to demonstrate intelligent behaviors in determined problem situations. There is no such thing as a more, or less, intelligent person, but there are individuals with intelligence potentials on different levels.

There are many terms used as synonyms of intelligence or intelligent: insight, talent, wit, gifted, cunning, lucid, vast memory (NAJMANOVICH, 2001). For Gardner (1999b), however, the applied term does not matter as long as all human manifestations are considered equally, without any one prevailing over the other.

It is a known fact that, still today, some schools consider individuals intelligent if they master logical-mathematics or verbal-linguistics. A pupil can more easily learn a determined content and present more learning difficulty of acquiring knowledge in different dimensions of human behavior. Thus, one who does not learn easily cannot be labelled as 'not intelligent'. No one likes to be felt "stupid", but labels tend to stick.

[...] being intelligent goes far beyond correctly responding to random questions or achieving good grades in texts and exams, aspects that are commonly scored and graded in our culture. It is true that the concept of intelligence can only be understood as expressions linked to the cultural context of all individuals according to the necessities presented by the environment they duel in. Scientifically, however, it is already possible to assert that intelligence encompasses many other potentials other than only those which correspond to academic success (NISTA-PICCOLO; SILVA; MELLO, 2018, p. 30 , our translation). 
Intelligent are not only the pupils who achieve success in their studies according to school standards. There are students who are classified as having 'Learning Difficulties' because they score poorly in certain evaluations imposed by the school. The human being can express intelligence in different situations, but physics, math, and logical thinking are not the most elevated expressions of knowledge. While some people are more skilled in that type of knowledge, others show to be more efficient in distinct activities such as sport, plastic arts, music and bodily tasks (GARDNER, 1995; 1999b).

"Bodily-kinesthetic intelligence is the ability to solve problems or to fashion products using one's whole body, or parts of the body. Dancers, athletes, surgeons, and craftspeople all exhibit highly developed bodily- kinesthetic intelligence" (GARDNER, 2006b, p. 50).

It is considered that this theory not only caused the change in vision about the human capacities but also changed the way of identifying how people manifest their intelligence, by no longer testing 'how' intelligent a person is, but interpreting 'in what manner or way one is intelligent'. This change sparked new debates on the human intelligence (NAJMANOVICH, 2001).

New discussions on this subject have generated more research and studies on the human cognition, enabling the understanding that individuals can change their intelligence potential, according to the stimuli received in their surroundings. The cultural context is what defines what is valued as intelligent, such that the opportunities for challenges can amplify the potential of responses to problem situations. According Zylberberg (2007, p. 31, our translation) “[ ...] people have a wide spectrum of capacities and one person's potential performance in a determined area cannot translate into the same performance in another".

Gardner $(1994 ; 1995 ; 1999 b)$ defined the nine types of intelligence, of which eight were consolidated. The author never knows how many there are, but knows they are not infinite, as they are strictly related to the cultural context. The author defined them as follows:

- Two intelligences are most valued in different contexts, mainly by schools: logicalmathematical, demonstrated by abstract reasoning, logical organization of thoughts, numbers, formulas and calculations; verbal-linguistic, which involves the rhetoric capacity of language, the potential of learning by rote, of explanations and conceptualizations, in oral and written form. These two intelligences have always prevailed in teaching and psychological tests, but this does not guarantee their superiority over the other intelligences. 
- Three intelligences are highlighted by their originality in being classified under the status of intelligence: musical-rhythmic, represented by the skills of musicians, composers, and connoisseurs with a high level of musical perception and emotional sensibility to sounds and rhythms; visual-spatial, demonstrated by the manipulation of special view patterns with a sense of direction and skill at reproducing mental images, with the ability of dealing with issues of time/space; bodily-kinesthetic, perceived in people who have great control of the movement of the limbs or their entire body with skill and dexterity, such as dancers, athletes, artisans, surgeons and mechanics who have domain of the body and motor refinement.

- Gardner highlighted another two intelligences - the personal intelligences, considered as the most important since they influence the attitudes and actions of people in their daily life. These are interpreted as: interpersonal, expressed through the relations with other people, by demonstrating the capacity of observing moods and intentions that affect relations; intrapersonal, demonstrated by a balanced control of reactions under emotional contexts, knowing oneself to an extent that one can self-motivate to accomplish decisions and actions, and regulate desires, impulses and fears.

- Gardner presented two more intelligences, while one is still unconsolidated: the existential intelligence. Despite the fact that the author considers the existential capacity as a domain that distinguishes people, he still cannot attribute to it a status of intelligence based solely on cues present in life experiences. It is necessary to review the criteria used in listing the other intelligences presented; the naturalist intelligence, highlighted in people who present skills in dealing with nature, and who have an unrivalled knowledge on the classifications and peculiarities of wildlife and plant life in their environment (NISTAPICCOLO, 2014).

This perspective of the human performance provided educators with a more careful look on the principles that guide the Theory of Multiple Intelligences and positively resonated their teaching practices. For teachers, a new form of interpreting the potential of their students enabled them to develop new ways to teach. According to Gardner (1999b), if we have diversified potentials, we learn through different pathways and express our knowledge differently.

In Gardner's view, the purpose of school should be to develop intelligences. Teachers can help their students reach vocational goals that are appropriate to their spectrum of intelligences (GARDNER, 2006b).

Based on this reflection, it is possible to reconstruct teaching practices that are oriented to student learning; observing the method through which the content was given provides the student with the easiest path for the student to learn and results in significant learning and problem solving, underlining new strategies while teaching (NISTA-PICCOLO, 2010). 


\begin{abstract}
According to Gardner himself, teachers need to formulate their teaching practices based on two pillars: recognizing the difficulties faced by students to understand specific concepts and taking into account the mental differences of students. If people learn through different pathways, the pathway and comprehension of content must vary. Therefore, one cannot teach from a single entry point and expect it to be accessible by everyone (NISTA-PICCOLO, 2014, p. 61, our translation).
\end{abstract}

\title{
4 A new look at Physical Education classes in school
}

After decades of reflecting on the implications of the Theory of Multiple Intelligences in the educational area, the author highlights that there are two crucial points for educators: respecting the difference between individuals and allowing every child to have an ideal education and teaching, whichever be the content, in many ways, thus awakening the different intelligences and their combinations (GARDNER; CHEN; MORAN, 2010). More important than recognizing the individual differences is to value them.

Thinking of these principles when substantiating Physical Education classes turns the attention to the bodily practices developed in the context of schooling, interpreted as an expression of a language, developed within a learning process ruled by singularity and diversity and as a space for stimulating bodily intelligence.

For Gardner (1994):

[...] the body is more than simply another machine. It is indistinguishable from the other artificial objects in the world. It is also the recipient of the sense of self and of the individual, the feelings and more personal aspirations, as for the entity to which others respond in a special way, given one's human qualities (p. 183, our translation).

[...] the functioning of the motor system is incredibly complex and demands the coordination of an astounding variety of neural and muscular components in a very differentiated and integrated manner (p. 164, our translation).

The body's movement control center is located in the primary motor cortex, being each cerebral hemisphere the motor representation of the contralateral side of the body. Gardner (2006a) highlights the apraxia as one line of evidence for bodily-kinesthetic intelligence. There is a clearly defined developmental schedule in children for body movement. Students can build skills by using their bodies to express emotions by dancing, playing a sport's game, or creating different body movements - these evidence the cognitive features of body usage in their school classes. 
It's possible to incorporate a bodily-kinesthetic intelligence across the curriculum when teaching science, social studies, mathematical concepts through gymnastics, dance, and other bodily activities. However, a new idea must first be assimilated into assumptions and subsequently transformed into practice. Establishing new practices in any domain is challenging. The process of implementing changes to educational activities takes years. MI ideas cannot be the final goal of the educational system. One can only apply the MI theory after careful analysis of its principles.

[...] because MI theory stipulates neither what to teach nor how to teach it, one could teach English literature or theory of mechanics by using a number of different lesson plans or by giving students software that draws on their various intelligences [...]. The point is that there is no direct tie between a scientific theory and a set of educational moves (GARDNER, 1999b, p. 144).

It is up to the teacher to develop instruments in pedagogical actions for teaching students, respecting each one's individual limits while still opening doors for increasing their motor-skill baggage. The educator is the mediator of problem situations to be experienced, to reach the basic needs in motor development and improvement of the students. By mediating the learning process, their proposed activities must stimulate the potential of kinesthetic bodily intelligence, but also enable the exploration of other intelligences in the activities at hand.

Motric education can occur upon the recognition of oneself, represented by the development of an intrapersonal intelligence; it can materialize as one's relationship with others, emphasizing the interpersonal intelligence; it can be experienced in different dimensions of space and time, turning to the stimulation of a spatial intelligence. It can result in the expression of language and logical thoughts which aim toward the refinement of verbal and mathematical intelligences; and it may signify the corporeality of the subject in the variations of the stimulation of one's kinesthetic bodily intelligence (NISTA-PICCOLO, 2010, p. 67-68, our translation).

To recognize the bodily activities as a manifestation of intelligence is to respect the corporeality of the individual and comprehend movement as a possibility of exploring the potential at hand.

If the body is so fundamentally embedded in all our mental processes, it follows that we need to return to the body to cash in the semantic values of language. [...] the body is able to be aligned with linguistic expressions or, more accurately, is able to inform otherwise empty verbal schemata (RUTHROF, 2000, p. 105). 
We assume that [...] "in a world under the rule of logic gates, corporeality would be superfluous" (RUTHROF, 2000, p. 177). The only way to conceive corporeality is to recognize it as an intelligence potential.

The expression of corporeality occupies a wide spectrum in Physical Education classes. Despite not occurring only in experiences from these classes, it is in the motricity that the body expresses itself, expressing emotions, intelligent behaviors, and relationships with others. "We are our bodies. Our corporeality is the visible dimension of the invisibility of intelligence" (ZYLBERBERG, 2007, p. 100, our translation).

Living the corporeality in its multiple possibilities is not yet a reality in our school system. Reframing the different forms of teaching, deconstructing the assumption of an ideal body, brought forth by the cultural society, can occur over the choice of the teaching practices. Thus, the teacher is central in this process of building awareness in students about the issues, which concern their corporeality, helping them in the discovery of their potentials so they can manifest their knowledge (NISTA-PICCOLO, et al., 2019, p. 12, our translation).

The teaching of bodily practices with a look on corporeality of the subject provides for an education of sensibility, promotes respect for individuality in its particularities and pluralities and values the possibility of expression of the other.

In this new century, the education of corporeality of the self - since the self learns through the entire body - demands the complexity of thought in which one over many, certain and uncertain, logical and contradictory are in intimate association and always include the observer in the observation (NISTA-PICCOLO, 2014, p. 63, our translation).

In order to reflect on teaching in the learning process, it is necessary to understand the pupil in his or her complexity. Therefore, it is possible to state that: "[...] we conceive humans as complex, whole, unique and based on their corporeality so as to then formulate the teaching and learning process as a form of stimulating the intelligences" (BRANDL, 2005, p. 34, our translation).

Because teachers often do not know different mechanisms through which students learn, they elaborate activities for Physical Education classes in school without observing "the routes for easier learning, or they are even unable to detect the reasons which impair some students from learning” (ZYLBERBERG; NISTA-PICCOLO, 2008, p. 59, our translation), and also without identifying the potentiality of their pupils, thus labelling them as incompetent. 
The application of the Theory of Multiple Intelligences in Physical Education classes can induce teachers to enhance their repertoire of strategies by finding new routes to learning and bypassing the linguistic and logical techniques that are common in the school environment.

To contribute to the stimulation of the kinesthetic bodily intelligence, it is up to Physical Education teachers to adjust this knowledge to the area and provide a rich and challenging environment for students. This must be done by using pedagogical interventions that favor thought and creation over memorization and repetition, since the universe of motor responses to problems of our culture is diversified and vast, overcoming the cultural tradition, which advocates, for Physical Education classes, the acquisition and transmission of standardized and mechanical movements of games, sports, gymnastics and dance (BRANDL, 2005, p. 119, our translation).

\section{To close...}

Physical Education classes that are developed under a new mindset must contemplate conceptual, procedural, factual and behavioral concepts as well as other areas of knowledge. Nista-Piccolo and Moreira (2012b, p. 43), state that:

Understanding how to teach is to promote the opportunity for knowledge by offering the means and instruments that will enable the students to their own construction. The pedagogical context is related to the creation of challenges that provoke an imbalance to students, promoting growth and urging them to move forward. For this, however, it is necessary to respect the students' limitations and recognize their potential, assisting them in finding the easiest route to effective learning. (our translation)

As opposed to Physical Education classes which are limited to "playing soccer" (an interpretation of the practice in soccer), the activities proposed must offer the students with opportunities to synthesize new motrice experiences. Classes that propose challenges and strategies though problem situations, with the intent of consolidating significant learning.

A careful consideration in the choice of what and how to teach runs through issues that implicate the school's participation as, for example, the environment created for learning, the available teaching materials, and the defined transversal themes. Thus, everything that is influenced by the school's Pedagogical Project and that guides the teaching practices. Though is also important to highlight that, in order to meet the principles of the Theory of Multiple Intelligences, the school must not necessarily hold this theory as a basis for the activities, but the teachers must simply include a differentiated analysis of the performance of the students in class in order to recognize their potentialities. 
Teaching something to someone requires attention both to the methodological strategies chosen as to the environment where it is taught. However, more important is to verify up to what point the "form used to teach" is consistent with the pathways that enable the learning of our students (NISTA-PICCOLO; VECCHI, 2006, p. 148, our translation, emphasis added).

The autonomy of the educator does not depend on the implementation of a pedagogical model external to the classes since the commitment as a "social actor" demands a reflection of one's conscious attitudes in the construction of knowledge for the students, adopting continuous individual and collective evaluation (GIESTA, 2005, p. 38, our translation). The educator may also contribute to the acquisition of autonomy for the participating students, providing situations in which they develop critical thinking with the objective of transforming their daily life. This gain in autonomy develops from the teacher/student interrelationship in the process of independence of their school activities. To contribute effectively, however, it is necessary to know the students within and beyond the school walls.

According to Gardner (1999b, p. 151), to know each student:

[...] means learning about each student's background, strengths, interests, preferences, anxieties, experiences and goals, not to stereotype or preordain but rather to ensure that educational decisions are made on the basis of an up-to-date profile of the student. [...] Whatever their philosophies, good teachers, tutors, and coaches have always sought to know their students well.

The best teachers rarely use formal instruments to identify unique characteristics. Contrarily, they observe and reflect on their students' behavior. The theory of multiple intelligences can be utilized as an excellent initial organizer in this process.

By knowing the strengths and weaknesses of students, it will be possible to stimulate not only the domains they find easier, but also their more fragile performances, where they encounter more difficulty to perform. For this, one needs to troubleshoot different situations. The creation of problems will surprise students with a new exercise and a challenge to overcome, provoking their creativity. The problem situation must provoke willingness, necessity, and self-motivation in the search for a solution; it must be an original, creative and unanticipated problem.

An important characteristic of the problem situation is that it must defy us to an action that is, on one hand, structured by the coordinates that forge it and, on the other, expressed here and now. In other words, one of the obstacles of a problem situation is to articulate diversity with singularity. Diversity, because its algebra can be expressed in various forms, despite each case being unique and demanding an understanding that is never repeated (PERRENOUD et al., 2002, p. 114, our translation). 
Howard Gardner, by implementing the Theory of Multiple Intelligences, broke paradigms and enabled advances in scientific research, which allows for a new look "to the other" when presenting the thesis of the plurality of the mind. For the author, the central ideas can be transmitted to a multiplicity of representations that strongly contribute to the educational area, emphasizing the possibility of teaching through different entry points and providing a new approach to the interpretation of student performance.

The art of teaching, however, consists precisely in resisting formulas. [...] the teacher's task is similar to that of a maestro of an orchestra who memorizes the entire core within the mind but can still mold it to the requirements of specific musicians. One must propose subjects, tasks, and interpretations, which seamlessly combine, captivate and absorb the students and, lastly, help the vast majority of students to obtain a deeper understanding of each subject (GARDNER, 1999a, p. 247, our translation).

Inspired by the principles of the plurality of mind and multiplicity of intelligence behaviors, the teacher can promote growth, stimulate their students to move forward and master their potentials, recognizing their different learning pathways during Physical Education classes in school. By doing so, education may achieve its greatest purpose of human development.

\section{Referências}

BRANDL, C. E. H. A estimulação da inteligência corporal cinestésica no contexto da educação física escolar. 2005. 194f. Tese (Doutorado em Educação Física) - Faculdade de Educação Física, Universidade Estadual de Campinas, Campinas, 2005.

CORREIA, W. R. Educação física no ensino médio: questões impertinentes. 2. ed. Jundiaí: Fontoura, 2011.

GARDNER, H. Estruturas da mente: a teoria das inteligências múltiplas. Porto Alegre: Artes Médicas, 1994.

GARDNER, H. Reflections on multiple intelligences myths and messages. Phi Delta Kappan, Arlington, n. 77, p. 200-209, 1995.

GARDNER, H. O verdadeiro, o belo e o bom: princípios educacionais para uma nova educação. Rio de Janeiro: Objetiva, 1999a.

GARDNER, H. Intelligence reframed: multiple intelligences for the 21st century. New York: Basic Books (Perseus Books Group), 1999 b.

GARDNER, H. Multiple intelligences: new horizons. New York: Basic Books (Perseus Books Group), 2006a.

GARDNER, H. The Development and Education of the Mind: the selected works of Howard Gardner. New York: Routledge (Taylor \& Francis Group), 2006 b.

GARDNER, H.; CHEN, J. Q.; MORAN, S. Inteligências múltiplas ao redor do mundo. Porto Alegre: Artmed, 2010. 
GIESTA, N. C. Cotidiano escolar e formação reflexiva do professor: moda ou valorização do saber docente? 2. ed. Araraquara: Junqueira \& Marin, 2005.

MOREIRA, E. C.; NISTA-PICCOLO, V. L. (org.). O quê e como ensinar educação física na escola. Jundiaí: Fontoura, 2009.

MOURA, D. L. A BNCC: ensino fundamental e ensino médio. In: CARREIRA FILHO, D.; MOURA, D. L.; SILVEIRA, S. R.; CORREIA, W. R. (org.). Educação física no ensino médio: questões e reflexões. Curitiba: Editora CRV, 2019. v. 39. p. 47-58.

NAJMANOVICH, D. O sujeito encarnado: questões para pesquisa no/do cotidiano. Rio de Janeiro: DP\&A, 2001.

NISTA-PICCOLO, V. L. Educação física, escola e as inteligências múltiplas. In: MOREIRA, W.W.; SIMÕES, R.; VIRTUOSO JÚNIOR, J. S.; BARBOSA NETO, O. (org.). Educação física, esporte, saúde e educação. Uberaba: UFTM, 2010. p. 51-70.

NISTA-PICCOLO, V. L. A teoria das inteligências múltiplas: o que é ser inteligente? In: BALBINO, H. F. (org.). Inteligências múltiplas: uma experiência em pedagogia do esporte e da atividade física no Sesc São Paulo. São Paulo: Edições Sesc São Paulo, 2014.

NISTA-PICCOLO, V. L.; MOREIRA, W. W. Corpo em movimento na educação infantil. São Paulo: Cortez, 2012a.

NISTA-PICCOLO, V. L.; MOREIRA, W. W. Esporte como conhecimento e prática nos anos iniciais do ensino fundamental. São Paulo: Cortez, 2012b.

NISTA-PICCOLO, V. L.; SILVA, Y. M. da; MELLO, F. L. de. A inteligência humana e o cotidiano escolar. Série-Estudos, Campo Grande, v. 23, n. 47, p. 27-41, jan./abr. 2018.

NISTA-PICCOLO, V. L.; VECCHI, R. L. A Educação física escolar na perspectiva do ensino para a compreensão. In: POGRÉ, P.; LOMBARDI, G.; EQUIPE DO COLÉGIO SIDARTA (org.). O ensino para a compreensão: a importância da reflexão e da ação no processo de ensino-aprendizagem. Espírito Santo: Hoper, 2006. p. 147- 155.

NISTA-PICCOLO, V. L. et al. As inteligências expressas na corporeidade vivida no cotidiano escolar. Educação e Cultura Contemporânea, Rio de Janeiro, v. 16, n. 44, p. 369-393, abr. /jun. 2019.

PERKINS, D. Outsmarting: the emerging science of learnable intelligence. New York: The Free Press, 1995.

PERRENOUD, P. et al. As competências para ensinar no século XXI: a formação dos professores e o desafio da avaliação. Porto Alegre: Artmed, 2002.

RUTHROF, H. The body in language. New York: Cassell, 2000.

TOLEDO, E.; VELARDI, M.; NISTA-PICCOLO, V. L. Os desafios da educação física escolar: seus conteúdos e métodos. In: MOREIRA, E. C.; NISTA-PICCOLO, V. L. (org.). O quê e como ensinar educação física na escola. Jundiai: Fontoura, 2009. p. 21-26.

ZYLBERBERG, T.P. Possibilidades corporais como expressão da inteligência humana no processo ensino-aprendizagem. 2007. 280f. Tese (Doutorado em Educação Física) - Faculdade de Educação Física, Universidade Estadual de Campinas, Campinas, 2007.

ZYLBERBERG, T. P.; NISTA-PICCOLO, V. L. As contribuições dos estudos sobre inteligência humana para a pedagogia do esporte. Revista Pensar a Prática, Goiás, v. 11, n. 1, p. 59-68, jan./jul. 2008. 